\title{
Assessment of the gluten content in gluten-free labeled foods: comparison of two gluten detection methods
}

\author{
Álvaro Macedo Laureano ${ }^{1}$ e Themis Reverbel da Silveira ${ }^{2}$
}

This study was designed to compare the effectiveness of the R5-ELISA and immunochromatographic assays in detecting gluten in foods labeled gluten-free and to determine if the immunochromatographic method is a sensitive and reliable method for detecting gluten at safe levels for celiac patients. We analyzed seventy different commercially foods available in Brazil, labeled "gluten-free". Gluten was extracted by ethanol precipitation and, subsequently, analyzed using a commercial immunochromatographic test and ELISA kit, both based in a monoclonal antibody. The analysis of sensitivity and specificity was made using the kappa coefficient. More than a quarter of the samples $(28.6 \%$ ) analyzed by ELISA contained levels of gluten greater than $5 \mathrm{mg} / \mathrm{kg}$. Almost half of these (12.9\%) exhibited levels that exceeded $20 \mathrm{mg} / \mathrm{kg}$, the maximum gluten level recommended by the Codex Alimentarius for a naturally gluten-free product. We found $27.1 \%$ of the samples tested positive in the immunochromatographic test. There was no statistically significant difference between the results of the ELISA (detection value $\geq 5 \mathrm{mg} / \mathrm{kg}$ ) and the immunochromatographic test. Comparing the ELISA ( $\geq 5 \mathrm{mg} / \mathrm{kg}$ ) and immunochromatographic test, we obtained $90 \%$ sensitivity and $98 \%$ specificity (Kappa of 0.89 ). We found gluten in a high proportion of the samples tested using both methods. In this study we also demonstrate that the immunochromatographic method is nearly as sensitive as the ELISA in detecting gluten levels and thus may serve as an inexpensive and rapid alternative to the R5-ELISA screening test.

Key-words: gluten-free foods, celiac disease, wholesome diet, food label compliance, Anvisa, analytical methods.

\section{Avaliação do teor de glúten em alimentos rotulados como livres de glúten: comparação de dois métodos de detecção}

O estudo foi desenhado com o intuito de comparar a eficácia dos testes R5-ELISA e imunocromatográfico de detectar glúten em alimentos rotulados como livres de glúten e para determinar se o método imunocromatográfico é sensível e confiável para detectar a proteína em níveis considerados seguros aos pacientes celíacos. Analisamos setenta alimentos disponíveis no Brasil, comercializados em embalagens fechadas, rotulados como livres de glúten. O glúten foi extraído com etanol e analisado utilizando fitas imunocromatográficas e Ensaio Imunoenzimático Ligado à Enzima (ELISA), ambos baseados em anticorpo monoclonal. Na análise por R5-ELISA, 28,6\% das amostras apresentaram teor de glúten acima de $5 \mathrm{mg} / \mathrm{kg}$. Em $12,9 \%$ foi detectado nível de glúten superior a $20 \mathrm{mg} / \mathrm{kg}$, o máximo tolerado pelo Codex Alimentarius para alimentos naturalmente livres de glúten. Quando testadas pelas fitas imunocromatográficas, 27,1\% das amostras apresentaram resultado positivo para a presença da proteína. Não encontramos diferença significativa entre os resultados do R5-ELISA iguais ou superiores a $5 \mathrm{mg} / \mathrm{kg}$ de glúten e os positivos para o teste

\footnotetext{
${ }^{1}$ Hospital de Clínicas de Porto Alegre, Programa de Pós-Graduação: Ciências em Gastroenterologia, Faculdade de Medicina, Universidade Federal do Rio Grande do Sul (UFRGS), Porto Alegre, RS.

Correspondência: Rua Ramiro Barcelos, 2350, CEP 90035-903, Porto Alegre, RS. E-mail: alvarol@pop.com.br

${ }^{2}$ Hospital de Clínicas de Porto Alegre, Programa de Pós-Graduação: Ciências em Gastroenterologia, Faculdade de Medicina, Universidade Federal do Rio Grande do Sul (UFRGS), Porto Alegre, RS.
} 
imunocromatográfico. Ao compararmos o R5-ELISA $(\geq 5 \mathrm{mg} / \mathrm{kg}$ de glúten) com o método imunocromatográfico, encontramos uma sensibilidade de $90 \%$ e especificidade de $98 \%$, (Kappa = 0,89). A presença de glúten foi observada em uma alta proporção das amostras utilizando os dois métodos. Demonstramos que o teste imunocromatográfico é sensível para a detecção de glúten em níveis seguros aos portadores de doença celíaca e pode servir como uma alternativa barata e rápida ao R5-ELISA.

Palavras-chave: alimentos sem glúten, doença celíaca, alimento seguro, veracidade da rotulagem, Anvisa, métodos analíticos.

\section{INTRODUCTION}

Celiac disease (CD) is a chronic inflammatory autoimmune enteropathy triggered in genetically susceptible individuals by the ingestion of food containing gluten. The symptoms and clinical manifestations of $\mathrm{CD}$ are highly variable among affected individuals [1]. CD occurs varying from asymptomatic, to symptoms and sequelae of intestinal malabsorption and even presents other symptoms that are not gastrointestinal ones - like osteoporosis, infertility, short stature, cancer [2]. The only treatment for $\mathrm{CD}$ is a lifelong exclusion of wheat, barley and rye from the diet. Though seemingly straightforward, dietotherapy as a remedy for $\mathrm{CD}$ is difficult in practice given the prevalence of wheat products in foodstuffs, the improper or non-standard labeling of gluten-free foods, and gluten cross-contamination [3]. The clinical experience suggests that part of celiacs clinical recurrence is from an inadvertent consumption of gluten.

CD affects nearly $1 \%$ of the population, varying among different ethnic groups [4]. Studies have shown a prevalence of biopsy-proven CD in 1:99 and 1:106 in Finnish [5] and Italian [6] schoolchildren, respectively. In adult populations in the UK and USA the seroprevalence was shown to be 1:87 [6] and 1:105 [7, respectively. CD is not uncommon in Brazil, where the prevalence was demonstrated to be 1:52 in pediatric outpatient ${ }^{[8]}$ and 1:681 in blood donors [9], with a bigger prevalence within special groups, like Down Syndrome with $8-12 \%{ }^{[10]}$ and first degree relatives with $4.8 \%{ }^{[11]}$.

The term "gluten" refers to a rubbery mass formed by the complex of proteins that remains after wheat flour is washed to remove starch and water soluble constituents [12]. This complex is composed of gliadins and glutenins, which are found at very similar proportions in most wheat varieties [13,14]. The gliadins belong to a family of proteins called prolamins and the glutenins to glutelins [15,16]. The term gluten is frequently used to refer specifically to the prolamin and glutelin content of wheat, though gluten is actually less narrowly defined as the insoluble proteins in wheat. It occurs naturally in other grains, including those that are not toxic to celiac [17]. However, the term gluten has been adopted by the CD community (both patients and health care professionals) as referring to either the gluten in wheat or the proteins that activate $\mathrm{CD}{ }^{[18]}$.

The aims of this study are to compare the results obtained with the two gluten detection methods and to evaluate the status of gluten in a variety of different gluten-free labeled foodstuffs.

\section{MATERIALS AND METHODS}

\section{Selection of samples for gluten testing}

Products tested were labeled as "gluten-free" or contained naturally gluten-free ingredients and were chosen because dietitians frequently recommend these products to people with CD. Different brands of the same gluten-free items were tested. Products were randomly collected between the years 2008-2009 from supermarkets and nutritional supplement stores located in Porto Alegre, Rio Grande do Sul. Foods containing chocolate were not included in this study because the polyphenol present in chocolate complicates sample testing.

\section{Analysis of gluten in samples}

Samples were first dehydrated and ground to a fine powder that was subsequently passed through a $600 \mu \mathrm{m}$ filter to ensure uniform sample size. Gluten was extracted using $60 \%$ ethanol. Briefly, $1 \mathrm{~g}$ of sample was dissolved in $10 \mathrm{ml}$ of aqueous $60 \%$ ethanol, homogenized and centrifuged. Pelleted material was collected and analyzed for the presence of gluten.

The detection and quantification of gluten was performed using the commercially available R5-ELISA kit Transia ${ }^{\circledR}$ Plate Prolamins (Ingenasa, Madrid, Spain) and the Rida ${ }^{\circledR}$ Quick Gliadin (R-Biopharm Inc., US) immunochromatographic test. The R5-ELISA method is a double antibody based sandwich ELISA performed 
in multiwell plates whereas the immunochromatographic test is a lateral flow assay that involves moving sample along a test strip.

The R5-ELISA assay was performed according to the protocol established by the Prolamin Working Group [14]. Briefly, samples are diluted and incubated for $1 \mathrm{~h}$ in separate wells on the R5-ELISA multiwell plate. The peroxidase-conjugated secondary antibody is then added to each well and incubated for 1 h. After washing the wells, the enzymatic substrate tetramethylbenzidine is added to each well. The reaction is stopped by the addition of $2.5 \mathrm{M}$ sulfuric acid, which results in the development of a yellow color. The intensity of the color signal was read at a wavelength of $450 \mathrm{~nm}$ using a Zenith 200rt microplate reader (Anthos-Labtec, Cambridge, UK). The assays used in this analysis specifically detect the prolamin content of gluten. According to the manufacturer's specifications, the sensitivity of the test is $1.5 \mathrm{mg} / \mathrm{kg}$ of gliadin. Results from the R5-ELISA were ready in $3 \mathrm{~h}$.

In the immunochromatographic test, the supernatant was first diluted in dilution buffer 1:11. The dipstick was subsequently placed inside the diluted sample and read after $5 \mathrm{~min}$. The results from this assay are read directly from the dipstick. Two bands are observed on the dipstick when gluten is detected, whereas only a single band is observed when gluten is not detected. If no band is visible, the result is invalid. The results of immunochromatographic test were available within $5-15 \mathrm{~min}$.

\section{Statistical evaluation}

For this study, seventy different products were selected for gluten testing. Table 1 shows the sample characterization. The number of samples tested in this study was determined based on similar studies performed in Brazil [19,20]. We estimated a confidence interval of $95 \%$ and margin of error $7 \%$. The results of immunochromatographic test were compared to those obtained in R5-ELISA using a McNemar test. All data were analyzed using the software SPSS 13.0.

\section{RESULTS}

The readouts of the two gluten detection assays compared in this analysis are different. In the case of the R5-ELISA, the results are quantitative whereas with the immunochromatographic the results are qualitative. For the immunochromatographic test, if gluten is present in amounts greater than $5 \mathrm{mg} / \mathrm{kg}$, the test gives a positive reading.

We chose two different cutoff values of the R5-ELISA to use as categorical variables in comparing results from the two assays: $5 \mathrm{mg} / \mathrm{kg}$, the limit of detection (LOD) of the immunochromatographic test, and $20 \mathrm{mg} / \mathrm{kg}$, the recommended Codex standard for gluten-free foods. Comparing the results of the immunochromatographic and the R5-ELISA at the 5 $\mathrm{mg} / \mathrm{kg}$ cutoff allows us to determine the sensitivity and specificity of the immunochromatographic test. Comparing results at the $20 \mathrm{mg} / \mathrm{kg}$ cutoff allows us to determine the suitability of the method for identifying foods that meet the recommended criteria of the Codex.

\section{Evaluation of gluten content in foods labeled as "gluten-free"}

Table 2 shows the results of the analysis from the R5-ELISA assay and the immunochromatographic test. Results from the R5-ELISA assay indicate that nine samples $(12.9 \%)$ had gluten levels higher than 20 $\mathrm{mg} / \mathrm{kg}$, the value recommended by the Codex for a naturally gluten-free food. Twenty samples $(28.6 \%)$ tested with gluten levels greater than $5 \mathrm{mg} / \mathrm{kg}$ (data shown in Figure). The results of the immunochromatographic test were positive in nineteen samples $(27.1 \%)$. There were no significant differences between results of R5-ELISA and those of immunochromatographic test $(p=1.00)$. The samples with gluten levels higher than $20 \mathrm{mg} / \mathrm{kg}$ are shown in Table 1.

\section{Evaluation of the sensitivity and specificity of the immunochromatographic test}

The analysis shows a sensitivity and specificity of $100 \%$ (CI 95\%: 71-100\%) and 83\% (CI 95\%: 72.7 $100 \%$ respectively for the immunochromatographic test when compared to the results from the R5-ELISA at the detection value of $20 \mathrm{mg} / \mathrm{kg}$. Evaluating the sensitivity and specificity of the immunochromatographic test compared to the R5ELISA assay using a detection value of $5 \mathrm{mg} / \mathrm{kg}$, we find a sensitivity and specificity of 90\% (CI 95\%: 70.798.3) and 98\% (CI 95\%: 90.5-99.9\%) respectively with a predictive negative value of $100 \%$ and a Kappa coefficient 0.89 . This demonstrates very good agreement between methods (see Table 3) [21,22]. 
Table 1. Types of foodstuffs analyzed and samples with gluten levels over $20 \mathrm{mg} / \mathrm{kg}$ analyzed by R5-ELISA.

Kind of food

Number of samples

$$
(n=70)
$$

Samples $>20 \mathrm{mg} / \mathrm{kg}$ $n$ (gluten level)
Chicken seasoning powder

Flour

Corn
Rice
Manioc
Soy
Banana

Pasta
Rice
Buckwheat

Cheese breads

Powder

Frozen

Cookies

Corn

Rice

Tapioca flour (polvilho)

Peanut

Soy

Quinoa

Snacks

Corn
Potato chips
Potato snack
Rice
Soy

Breads

$$
\begin{aligned}
& \text { Corn } \\
& \text { Manioc }
\end{aligned}
$$

Cereal bar

Granola

Soup powder
Beans
Corn

Pizza dough

\section{3}

6

4

3

3

1

3

1

2

2

5

4

4

1

1

1

(1)

$1(49.24)$

1 (52.97)

$2(55.15 ;>200)$

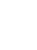

(1)

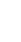

-
-
$1(52.28)$
-
-
-


Table 2. Analysis of gluten content in foods labeled "gluten-free".

\begin{tabular}{lcc}
\hline \multirow{2}{*}{ Methods } & Positive & Negative \\
\cline { 2 - 3 } & $n(\%)$ & $n(\%)$ \\
\hline Immunochromatographic & $19(27.1)$ & $51(72.9)$ \\
ELISA $>20 \mathrm{mg} / \mathrm{kg}$ & $9(12.9)$ & $61(87.1)$ \\
ELISA $>5 \mathrm{mg} / \mathrm{kg}$ & $20(28.6)$ & $50(71.4)$ \\
\hline
\end{tabular}

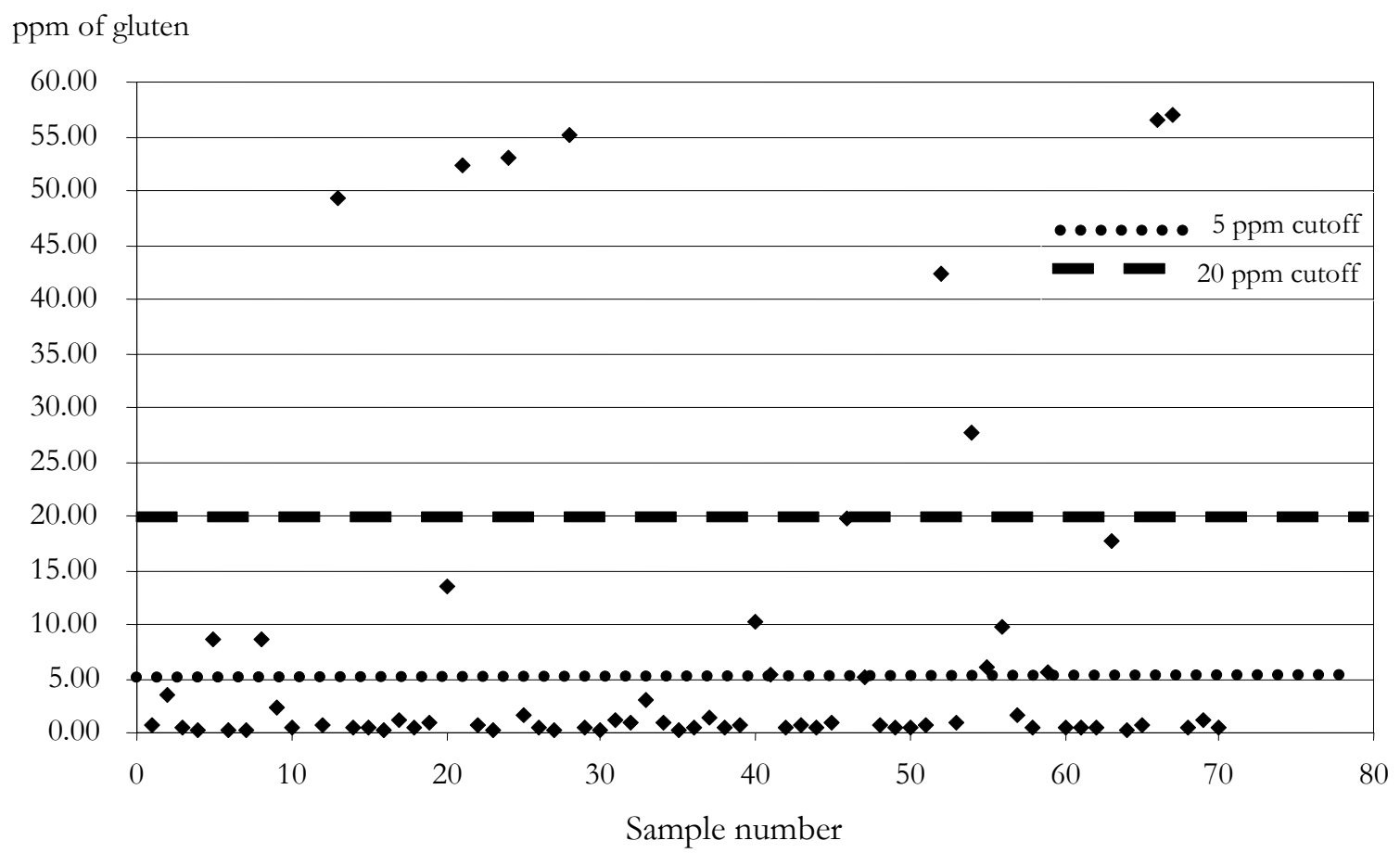

Figure. Distribution of gluten concentrations of the samples analyzed by R5 ELISA. In this figure the value recommended by the Codex for a food produced with naturally gluten-free ingredients to be considered gluten-free $(20 \mathrm{mg} / \mathrm{kg})$ and the LOD of immunochromatographic method $(5 \mathrm{mg} / \mathrm{kg})$ are highlighted. A sample with value over $200 \mathrm{mg} / \mathrm{kg}$ was omitted (sample no 11 - soy flour).

Table 3. Comparison of the two assays.

\begin{tabular}{cccccc}
\hline Assays & Sensitivity & Specificity & PPV * & NPV ** & Kappa \\
\hline Immunochromatographic x ELISA $>20 \mathrm{mg} / \mathrm{kg}$ & 100 & 83.6 & 47.4 & 100 & 0.57 \\
Immunochromatographic x ELISA $>5 \mathrm{mg} / \mathrm{kg}$ & 90 & 98 & 94.7 & 96.1 & 0.89 \\
\hline
\end{tabular}

$* \mathrm{PPV}=$ Positive Predictive Value ${ }^{* *} \mathrm{NPV}=$ Negative Predictive Value. 


\section{DISCUSSION}

The Codex Alimentarius Commission [23] has recommended gluten levels not exceed a maximum value of $20 \mathrm{mg} / \mathrm{kg}$ (ppm) for naturally gluten-free foods. For foods processed to reduce the gluten content to be considered gluten-free, the Codex recommends a maximum value of $200 \mathrm{mg} / \mathrm{kg}$. The Codex advises that assays designed to detect gluten should have a detection limit of at least $10 \mathrm{mg} / \mathrm{kg}$ gluten and recommends using the R5-ELISA (Enzyme Linked Immunosorbent Assay). The immunochromatographic test for gluten detection has a limit of detection (LOD) for gluten of $5 \mathrm{mg} / \mathrm{kg}$.

In Brazil, since 1992, a federal law asks for food manufacturers to warn about the presence of gluten on the label of their products [24]. In 2002, a federal resolution determined that the text "CONTÉM GLUTEN" (contains gluten) must be printed highlighted in foods and in non-alcoholic beverages [25]. In 2003 a federal law asked to print on labels of food and beverages the presence or absence of gluten with the texts "CONTÉM GLUTEN" and "NÃO CONTÉM GLUTEN" (contains no gluten) [26. Even though there are those federal laws, none of them establish an acceptable amount of gluten neither a method to ensure the quality of the product.

A disturbing percentage of foods labeled as gluten-free were determined to have gluten levels in excess of $20 \mathrm{mg} / \mathrm{kg}$, the maximum value recommended by the Codex. Like many countries, Brazil has laws that ask food manufacturers to warn consumers about the presence of gluten in their products [26]. Standards for gluten levels in foods have not yet been adopted and currently no monitoring system exists for systematically evaluating the gluten content in foods. Warnings on food labels are based on the ingredient list. No standardized scientific analysis is performed to ensure that the information on the labels is accurate.

The R 5 antibody, developed by Valdés et al. [14], recognizes the pentapeptide motif QQPFP of prolamins. This motif is thought to be responsible for inducing the abnormal immune response of celiac patients to wheat $[14,27,28]$. This antibody does not recognize prolamins that are not toxic to celiacs, for instance prolamins found in oat, rice and maize, reducing the risk of identifying false positives in gluten detection assays that utilize this antibody [29]. The R5ELISA assay is a quantitative method with a sensitivity of $3 \mathrm{mg} / \mathrm{kg}$ of gluten.
In recent years, other methods for gluten detection have been developed, such as mass spectrometry and DNA analysis [30]. These methods were not discussed in this paper, however, as our objective was to test a simple and less complicated assay for gluten detection.

The immunochromatographic assay is portable, easy to handle, and does not require specialized equipment. This assay gives reliable results in a short time (between 5-15 min) ${ }^{[3]}$ and results are expressed qualitatively (positive or negative) with an LOD of $5 \mathrm{mg} / \mathrm{kg}$ gluten. Given the advantages of the immunochromatographic assay, we believe the immunochromatographic assay might offer a better alternative to the R5-ELISA in determining the compliance of gluten labeling in foodstuffs."

According to Valdés et al. [14], gluten extraction should be performed using the Mendez cocktail, a solution containing the reducing agent 2mercaptoethanol and guanidine hydrochloride. Both reagents can cause skin or respiratory irritation and with chronic exposure they can be hazardous to the central nervous system. Because the aim of this study was to test a method that is simple and inexpensive, we chose to use the ethanol extraction procedure. For nonprocessed foodstuffs, extracting gluten using the cocktail yielded results only slightly higher than ethanol extraction, with an average 1.1-fold increase in the quantification of gluten. In foods heated to temperatures over $80^{\circ} \mathrm{C}$, gluten concentrations extracted using the cocktail were 3-fold higher than gluten concentrations obtained after ethanol extraction [31,32]. Though ethanol extraction is not as efficient as the cocktail in extracting gluten and may have led to underestimating the gluten content in processed foods, it likely reduces the risk of identifying false positives.

Celiacs must remain on a lifelong gluten-free diet. It is important that steps are taken to ensure celiac patients do not ingest gluten-contaminated food. Standards recommending safe limits for gluten levels in food must be instituted and the gluten levels of commercially available products should be monitored. In the present study, we have found that the immunochromatographic test is a sensitive and reliable method for detecting gluten in foods. The immunochromatographic test offers several advantages over the ELISA including the fact that it does not require the specialized equipment used in the R5ELISA assay. The immunochromatographic test could 
be a powerful tool for gluten testing of products to ensure that they are safe for people with CD.

As this is a preliminary study we accept that the number of samples analyzed was limited. We intend to follow up on this initial investigation and analyze more samples to better determine the percentage of improperly labeled gluten-free foods.

\section{CONCLUSIONS}

Using both the R5-ELISA assay and the immunochromatographic dipsticks, we detected gluten in foods labeled "gluten-free". The results from this preliminary study demonstrate that a high proportion of foods denoted as gluten-free in fact contain levels of gluten greater than the maximum limit recommended by the Codex. Our results further suggest that the immunochromatographic test is a sensitive and reliable method for detecting gluten. Given the ease with which the immunochromatographic test can be administered and the speed with which results can be obtained, the immunochromatographic test could prove a useful screening tool for gluten content in food products and the validation of product labels.

\section{ACKNOWLEDGEMENTS}

This study had financial support from the FIPE-HCPA (Fundo de Incentivo à Pesquisa do Hospital de Clínicas de Porto Alegre) and from the PROF-CAPES (Programa de Fomento à PósGraduação da Coordenação de Aperfeiçoamento de Pessoal de Nível Superior).

\section{REFERENCES}

[1] O'Leary C, Wieneke P, Healy M, Cronin C, O'Regan P, Shanahan F. Celiac disease and the transition from childhood to adulthood: A 28-year follow-up. Am J Gastroenterol. 2004;99(12):2437-41.

[2] Rostom A, Murray JA, Kagnoff MF. American Gastroenterological Association (AGA) Institute technical review on the diagnosis and management of celiac disease. Gastroenterology. 2006;131(6):1981-2002.

[3] Schubert-Ullrich P, Rudolf J, Ansari P, Galler B, Fährer M, Molinelli A, Baumgartner S. Commercialized rapid immunoanalytical tests for determination of allergenic food proteins: An overview. Anal Bioanal Chem. 2009;395(1):6981.

[4] Green PHR. Where are all those patients with celiac disease? Am J Gastroenterol. 2007;102(7):1461-3.
[5] Maki M, Mustalahti K, Kokkonen J, Kulmala P, Haapalahti M, Karttunen T, et al. Prevalence of Celiac disease among children in Finland. $\mathrm{N}$ Engl $\mathrm{J}$ Med. 2003;348(25):2517-24.

[6] Tommasini A, Not T, Kiren V, Baldas V, Santon D, Trevisiol C, et al. Mass screening for coeliac disease using antihuman transglutaminase antibody assay. Arch Dis Child. 2004;89(6):512-5.

[7] Fasano A, Berti I, Gerarduzzi T, Not T, Colletti RB, Drago $\mathrm{S}$, et al. Prevalence of celiac disease in at-risk and notat-risk groups in the United States: a large multicenter study. Arch Int Med. 2003;163(3):286-92.

[8] Brandt KG, Silva GA. [Seroprevalence of celiac disease at a general pediatric outpatient clinic]. Arq Gastroenterol. 2008;45(3):239-42.

[9] Gandolfi L, Pratesi R, Cordoba JCM, Tauil PL, Gasparin M, Catassi C. Prevalence of celiac disease among blood donors in Brazil. Am J Gastroenterol. 2000;95(3):689-92.

[10] Rodrigo L, Garrote JA, Vivas S. [Celiac disease]. Med Clin. 2008;131(7):264-70.

[11] Almeida PL, Gandolfi L, Modelli IC, Martins RC, Almeida RC, Pratesi R. Prevalence of celiac disease among first degree relatives of Brazilian celiac patients. Arqu Gastroenterol. 2008;45(1):69-72.

[12] Wieser H. Chemistry of gluten proteins. Food Microbiol. 2007;24(2):115-9.

[13] Hischenhuber C, Crevel R, Jarry B, Maki M, MoneretVautrin DA, Romano A, et al. Review article: safe amounts of gluten for patients with wheat allergy or coeliac disease. Aliment Pharmacol Ther. 2006;23(5):559-75.

[14] Valdés I, Garcia E, Llorente M, Mendez E. Innovative approach to low-level gluten determination in foods using a novel sandwich enzyme-linked immunosorbent assay protocol. Eur J Gastroenterol Hepatol. 2003;15(5):465-74.

[15] Shewry PR, Halford NG, Belton PS, Tatham AS. The structure and properties of gluten: An elastic protein from wheat grain. Philos Trans R Soc Lond B Biol Sci. 2002;357(1418):133-42.

[16] van den Broeck HC, America AHP, Smulders MJM, Bosch D, Hamer RJ, Gilissen LJWJ, et al. A modified extraction protocol enables detection and quantification of celiac disease-related gluten proteins from wheat. J Chromatogr B Analyt Technol Biomed Life Sci. 2009;877(10):975-82.

[17] Kasarda DD. The Grain. Greenbelt: Department of health and human services food and drug administration center for food safety and applied nutrition 2005:85-90 [cited 
2009 Aug. 12]. Available from: http://www.docstoc.com/docs/14023186/1DEPARTMENT-OF-HEALTH-AND-HUMANSERVICES-FOOD-AND-DRUG

[18] Jabri B, Kasarda DD, Green PHR. Innate and adaptive immunity: The Yin and Yang of celiac disease. Immunol Rev. 2005;206:219-31.

[19] Abreu RW, Barbosa SFC, Torre JCMD, Lichtig J, Zenebon O. Detecção de glúten em alimentos por meio de ELISA. Rev Inst Adolfo Lutz. 2007;3(65):176-80.

[20] Hirayama KB. Assessment of gluten in homemade foods prepared by celiac disease patients and/or their caretakers [tese]. São Paulo: Universidade Federal de São Paulo; 2007.

[21] Altman DG. Pratical statistics for medical research. London: Chapman \& Hall; 1991.

[22] Landis JR, Koch GG. The measurement of observer agreement for categorical data. Biometrics. 1977;33(1):15974.

[23] Codex Alimentarius. Standard for Foods for Special Dietary use for Persons Intolerant to Gluten. Vol 4. Rome: Italy; 2008.

[24] Brasil. Lei no 8543, de 23 de dezembro de 1992. Determina a impressão de advertência em rótulos e embalagens de alimentos industrializados que contenham glúten a fim de evitar a doença celíaca ou síndrome celíaca. Diário Oficial da União, Brasilia, 24 dez. 1992. Seção 1, p. 7.

[25] Brasil. Agência Nacional de Vigilância Sanitária. Resolução RDC no 40, de 08 de fevereiro de 2002. Regulamento Técnico para Rotulagem de alimentos e bebidas embalados que contenham glúten. Diário Oficial da União, Brasilia, 13 fev. 2002. Seção 1, p. 34.

[26] Brasil. Lei no 10.674, de 16 de maio de 2003. Obriga a que todos os produtos alimentícios informem sobre a presença de glúten, como medida preventiva de controle da doença celíaca. Diário Oficial da União, Brasília, 16 maio 2003. Seção 1, p. 1.

[27] Kahlenberg F, Sanchez D, Lachmann I, Tuckova L, Tlaskalova H, Mendez E, et al. Monoclonal antibody R5 for detection of putatively coeliac-toxic gliadin peptides. Eur Food Res Technol. 2006;222(1-2):78-82.

[28] Osman AA, Uhlig HH, Valdes I, Amin M, Méndez E, Mothes T. A monoclonal antibody that recognizes a potential coeliac-toxic repetitive pentapeptide epitope in gliadins. Eur J Gastroenterol Hepatol. 2001;13(10):1189-93.

[29] Mendez E, Vela C, Immer U, Janssen FW. Report of a collaborative trial to investigate the performance of the R5 enzyme linked immunoassay to determine gliadin in glutenfree food. Eur J Gastroenterol Hepatol. 2005;17(10):1053-63.

[30] Wieser H, Koehler P. The Biochemical Basis of Celiac Disease. Cereal Chem. 2008;85(1):1-13.

[31] Doña VV, Fossati CA, Chirdo FG. Interference of denaturing and reducing agents on the antigen/antibody interaction. Impact on the performance of quantitative immunoassays in gliadin analysis. Eur Food Rese Technol. 2008;226(3):591-602.

[32] Garcia E, Llorente M, Hernando A, Kieffer R, Wieser H, Mendez E. Development of a general procedure for complete extraction of gliadins for heat processed and unheated foods. Eur J Gastroenterol Hepatol. 2005;17(5):529-39. 